\title{
PERAN DAN TANGGUNGJAWAB KEMENTERIAN LUAR NEGERI MELINDUNGI WNI DAN TKI DI LUAR NEGERI
}

\author{
Rumbadi \\ Dosen Tetap Prodi Ilmu Hukum Universitas Riau Kepulauan Batam
}

\begin{abstract}
ABSTRAK
Sempitnya lapangan pekerjaan di dalam negeri merupakan salah satu faktor pendorong generasi muda Indonesia dan tergolong usia muda mencari pekerjaan di Negara lain, tapi ada juga yang tujuan ke luar negeri bukan menjadi pekerja tapi melanjutkan pendidikan di jenjang lebih tinggi. Menurut Kementerian Luar Negeri Indonesia, yang paling banyak bermasalah adalah TKI selain kurangnya pendidikan, dan masih usia muda. Sayangnya kepergian para TKI keluar negeri ada yang tidak resmi, bahkan dari segi kelengkapan dokumen pun tidak memenuhi syarat sebagai pekerja di luar negeri.Akibatnya sering terjadi tindak kekerasan terhadap TKI oleh majikan di tempat mereka bekerja. Tak jarang pula kasus-kasus yang timbul bermuara ke proses hukum, yang tentu saja hukum diterapkan adalah hukum di negera tempat TKI bekerja. Hukum cambuk, hukum mati, dan hukuman seumur hidup menjadi berita-berita surat khabar di tanah air. Namun Kementerian Luar Negeri tidak lepas tangan, dan menjalankan fungsi, peran dan tanggung jawabnya sesuai wakil Negara di luar negeri.Oleh sebab itu, diperlukan pencegahan terhadap calon TKI yang diketahui tidak layak menjadi pekerja di luar negeri, tidak hanya menyangkut usia tergolong muda, tapi juga pendidikan, dan kelengkapan dokumen lain sesuai dengan tujuan untuk menjadi pekerja. BNP2TKI sebagai lembaga yang bertanggungjawab dalam hal pencegahan harus membuka konter-konter di pelabuhan udara dan pelabuhan laut termasuk selidik pelabuhan tidak resmi yang menjadi tempat pengiriman TKI illegal tersebut.
\end{abstract}

Kata Kunci: kementerian Luar Negeri, WNI dan TKI 


\section{PERAN DAN TANGGUNGJAWAB KEMENTERIAN LUAR NEGERI MELINDUNGI WNI DAN TKI DI LUAR NEGERI}

\section{A. PENDAHULUAN}

Kurang tersedianya lapangan kerja di tanah airmenyebabkan warga Negara Indonesia memilih bekerja di luar negeri. Selain itu, terminologi upah murah menjadikan pekerja Indonesia yang selanjutnya disebut TKI dianggap mendapat upah yang tidak layak di dalam negeri, sementara bekerja di luar negeri upah yang akan diterima memberi harapan bakal adanya perubahan sosial khususnya menyangkut kesejahteraan.

Perusahaan Pengerah Tenaga Kerja Indonesia Swasta (PPTKIS) pun tumbuh dan berkembang.Akibatnya terjadi persaingan yang ketat, dan diantara PPTKIS ada yang tidak profesial. Dikatakan tidak professional karena dalam menerima calon Tenaga Kerja Indonesia yang selanjutnya disingkat TKI tidak jujur dengan cara memalsukan dokumen seperti usia yang sejatinya usia 13 tahun dibuat menjadi 20 tahun, selain itu menyangkut pendidikan, serta pelatihan yang sertifikatnya dibuat tidak sesuai dengan kompetensi calon TKI tersebut. Perbuatan ini berakibat pada TKI yang bekerja di luar negeri mendapat perlakuan kurang manusiawi oleh majikan karena dianggap tidak mampu bekerja. Penyiksaan, dikejar-kejar polisi di negera tempat bekerja, hingga mendapat sanksi hukum berat seperti hukuman seumur hidup, hukuman mati dengan cara digantung dan lainlain.Tambahan keberangkatan TKI melalui jalur illegal, yang ini banyak terdapat di Kepulauan Riau khusunya Batam.

Kasus Walfrida, TKI asal Dusun Kolo Ulun, Desa Faturika, Kecamatan Raimanuk, Kabupaten Belu, Kupang, Nusa Tenggara Timur terancam hukuman mati. Wanita kelahiran 12 Oktober 1993 yang ketika berangkat ke Malaysia tahun 2010 usianya 13 tahun. ${ }^{1}$ Usia yang masuk kategori belum dewasa dan cakapmembuat perjanjian sesuai tergambar dalam Pasal 1352 KUH Perdata. Dan

\footnotetext{
${ }^{1}$ Yohanes Seo-Orang-Tua-Walfrida-Diberangkatkan-ke-Malaysia-03 April 2016 Diambil pada 04 April 2016 dari http://m.tempo.co/read/news/2013/09/27/058517147/
} 
usia 13 tahun tergolong usia belum cakap untuk melakukan perjanjian sesuai peraturan perundang-undangan khususnya syarat sahnya perjanjian.

Dalam melakukan perjanjian maka ada 4 ( empat ) hal yang menjadi perhatian menurut Pasal 1320 Kitab Undang-Undang Hukum Perdata syarat sah suatu perjanjian sebagai berikut: ${ }^{2}$

\section{Adanya kesepakatan}

Kesepakatan tersebut mengikat dirinya dan terjadi persesuaian kehendak antar keduanya atau yang melakukan perjanjian, bahwa para pihak yang mengadakan perjanjian itu harus bersepakat, setuju untuk sepakat mengenai segala sesuatu yang diperjanjikan.Kata sepakat ini harus diberikan secara bebas, artinya tidak ada pengaruh dipihak ketiga dan tidak ada gangguan.

2. Cakap untuk melakukan suatu perikatan

Orang yang membuat suatu perjanjian harus cakap menurut hukum.Pada asasnya, setiap orang yang sudah dewasa atau akilbaliq dan sehat pikirannya, adalah cakap menurut hukum.

3. Suatu hal tertentu.

Apa yang diperjanjikan hak-hak dan kewajiban kedua belah pihak jika timbul suatu perselisihan. Barang yang dimaksud dalam perjanjian paling sedikit sudah harus ditentukan jenisnya, bahwa barang itu sudah ada atau sudah berada ditangan siberutang pada waktu perjanjian di buat.

4. Causa yang halal/ sebab-sebab yang halal

Causa atau sebab yang halal adalah isi perjanjian itu sendiri, dalam suatu perjanjian jual beli isinya adalah, pihak yang satu menghendaki uang, dalam perjanjian sewa-menyewa suatu pihak mengingini kenikmatan suatu barang, pihak yang lain menghendaki uang.

Walfrida yang berusia 13 tahun belum tergolong orang dewasa, sebab yang masuk kategori dewasa terbagi menjadi 2 (dua) yakni: ${ }^{3}$

\footnotetext{
${ }^{2}$ Ahmadi Miru dan Sakka Pati, Hukum Perikatan Penjelasan Makna Pasal 1233 sampai 1456 BW, Jakarta: Rajagrafindo Persada,hal.66 ${ }^{3}$ Andrian Ramadhan, kategori-umur-menurut-depkes-ri-2009. Diambil pada 05 April 2016 dari http://arfkomunika.blogspot.co.id/2014/01/
} 
1. Dewasa awal usia $12-16$ tahun

2. Dewasa akhir usia 17-25 tahun

Pada kasus yang diputus dalam kasasi di Mahkamah Agung, dengan Putusan MA RI No.477/K/ Sip./1976 tanggal 2 November 1976, majelis hakim membatalkan putusan pengadilan tinggi dan mengadili sendiri, yang dalam amarnya majelis hakim memutuskan bahwa ayah berkewajiban untuk memberian nafkah kepada anak hasil perkawinan yang putus tersebut sampai anaknya berumur 18 tahun. Majelis hakim berpendapat bahwa batasan umur anak yang berada di bawah kekuasaan orang tua atau perwalian ialah 18 tahun, bukan 21 tahun.Dengan demikian, dalam umur 18 tahun, seseorang telah dianggap mampu mempertanggungjawabkan perbuatannya, dan karenanya menjadi cakap untuk berbuat dalam hukum. ${ }^{4}$

Dilihat dari Undang-Undang No. 13 Tahun 2003 tentang Ketenagakerjaan Pasal 1 angka 26 maka:” Anak adalah setiap orang yang berumur di bawah 18 (delapan belas) tahun. Oleh sebab itu, dilihat dari ketentuan tersebut, Walfrida masih tergolong anak, dan masih dibawah pengawasan orang tua, dan apabila dipekerjakan sebagai tenaga kerja Indonesia, maka itu adalah perbuatan melawan hukum.

Disebut perbuatan melawan hukum karena tidak mengindahkan apa yang diamanatkan oleh peraturan perundang-undangan yang berlaku khususnya menyangkut syarat keterangan hari dan tanggal kelahiran Walfrida. R.Soesuli dalam bukunya berjudul: Kitab Undang-Undang Hukum Pidana (KUHP) serta komentar-komentarnya mengatakan bahwa yang diartikan dengan surat dalam bab ini adalah segalah surat, baik yang ditulis dengan tangan, dicetak, maupun ditulis memakai mesin tik, dan lain-lainnya. ${ }^{5}$

\section{B. PERUMUSAN MASALAH,}

Berdasarkan latar belakang yang dikemukakan diatas, maka peneliti dapat merumuskan masalah yaitu:

\footnotetext{
${ }^{4}$ Diana Kusumasari, perbedaan-batasan-usia-cakap-hukum-dalam-peraturan-perundang-undangan.Diambil pada05 April 2016 dari http://www.hukumonline.com/klinik/detail/lt4eec5db1d36b7

${ }^{5}$ Diambil pada Hari Selasa, tanggal 27 April 2016 dari www.hukumonline.com,
} 
1. Bagaimana peran Kementerian Luar Negeri melindungi Warga Negara Indonesia (WNI) dan Tenaga Kerja Indonesia (TKI) di luar negeri?

\section{METODE PENELITIAN}

Data yang dikumpulkan adalah data kualitatif maka teknik analisa datanya menggunakan model analisas kualitatif interaktif. Dalam teknik analisa data ini setelah data terkumpul selanjutnya bisa dikemukakan dalam sajian data ataupun dengan langkah mengolah data (mereduksi data) yang diperoleh dari sumber kepustakaan (literature-literatur, undang-undang, surat khabar maupun sumber kepustakaan lainnya), ataupun dari data-data yang diperoleh di lapangan dari informan yang berkompeten dalam memberikan data mengenai Warga Negara Indoneisa (WNI) dan tenaga kerja kerja (TKI) di luar negeri, berdasarkan Peraturan Menteri Luar Negeri RI Nomor 01/A/ OT/I/2006/01 Tahun 2006, Direktorat Perlindungan Warga Negara Indonesia dan Badan Hukum Indonesia (PWNI dan BHI) bertugas memberikan perlindungan WNI di dalam dan luar negeri, badan hukum Indonesia di luar negeri, pengawasan kekonsuleran, serta bantuan sosial dan repatriasi WNI.

Dalam penelitian ini, peneliti menggunakan jenis penelitian hukum normatif, yaitu asumsi dasarnyadari peraturan perundang-undangan. Kajian normatiF memandang hukum dalam wujudnya sebagai kaidah, apa yang menentukan apa yang boleh dan apa yang tidak boleh dilakukan. Kajian normative sifatnya preskriptif, yaitu bersifat menentukan apa yang salah dan apa yang benar. Kajian-kajian yang normatiF terhadap hukum antara lain: Ilmu Hukum Pidana dan Ilmu Hukum Tata Negara Positif. Dengan perkataan lain, kajian normative mengkaji law in books. ${ }^{6}$

\section{HASIN PENELITIAN DAN PEMBAHASAN}

Warga Negara Indonesia yang berada di luar negeri tidak hanya TKI, tapi ada pula mahasiswa dan/atau isteri yang ikut suaminya, atau sebaliknya.Namun yang sering menimbulkan persoalan adalah TKI karena keberadaan mereka illegal atau bekerja di luar negeri tanpa memiliki dokumen yang sah, dan kepergian TKI

\footnotetext{
${ }^{6}$ Prof.Dr. Achmad Ali,S,H,,M.H dan Dr.Wiwie Heryani,S.H..MH, Menjelajahi Kajian Empiris terhadap Hukum, Jakarta: Kencana Prenada Media Group, 2012. hal.1
} 
pun illegal, yang diantar oleh agen TKI melalui cara jalan pintas yang disebut pelabuhan tikus. Pelabuhan tikus ini banyak terdapat di Batam.

Di kota Batam, menurut catatan Imigrasi memiliki 7 (tujuh) tempat pemeriksaan imigrasi (TPI) laut yang berada di pelabuhan Sekupang, Kabil (pelabuhan barang), Harbor Bay, Batam Centre, Batu Ampar (pelabuhan barang), Marina City dan Nongsa. Selain itu juga terdapat 1 TPI udara yang berada di bandara Hang Nadim, Batam. ${ }^{7}$

Pelabuhan illegal itu tidak hanya digunakan untuk menyelundupkan TKI, tapi menjadi tempat masuknya warga Negara asing atau imigran gelap dari Negara-negara yang tengah konflik seperti Iran, Afganistan, dan lain-lain. Dan setelah TKI tiba di Negara yang dituju, maka di sini peran Kementerian Luar Negeri yang diwajibkan Negara untuk mencari, dan mengetahui dimana para TKI itu berada, apalagi terkait kasus.

\section{Fungsi BNP2TKI (Badan Nasional Penempatan dan Perlindungan Tenaga \\ Kerja Indonesia di Luar Negeri}

Di dalam negeri ada yang disebut Badan Nasional Penempatan dan Perlindungan selanjutnya disingkat BNP2TKI di Luar Neneri. Lembaga ini bertanggungjawab mencegah calon TKI dan/WNI bepergian keluar negeri dengan tujuan tidak jelas, atau tidak dilengkapi dokumen keimigrasian, atau dokumen ketenagakerjaan yang diatur di Negara tujuan dan Negara asal TKI.

Lahirnya BNP2TKI ketika pada 1994 Pusat AKAN dibubarkan dan fungsinya diganti Direktorat Ekspor Jasa TKI (eselon II) di bawah Direktorat Jenderal Binapenta.Namun pada 1999 Direktorat Ekspor Jasa TKI diubah menjadi Direktorat Penempatan Tenaga Kerja Luar Negeri (PTKLN). ${ }^{8}$

Dalam upaya meningkatan kualitas penempatan dan keamanan perlindungan TKI telah dibentuk pula Badan Koordinasi Penempatan TKI (BKPTKI) pada 16 April 1999 melalui Keputusan Presiden Nomor 29 Tahun 1999 Tentang Badan Koordinasi Penempatan Tenaga Kerja Indonesia yang

\footnotetext{
${ }^{7}$ Diambil pada 05 Mei 2016 dari - http://www.imigrasi.go.id/index.php/berita/berita-utama/280imigrasi-batam-sosialisasi-patroli-pelabuhan-tikus-ke-warga-pesisir

${ }^{8}$ Diambil pada 06 Mei 2016 dari- http://www.bnp2tki.go.id/frame/9003/Sejarah-PenempatanTKI- Hingga-BNP2TKI
} 
keanggotannya terdiri 9 instansi terkait lintas sektoral pelayanan TKI untuk meningkatkan program penempatan dan perlindungan tenaga kerja luar negeri sesuai lingkup tugas masing-masing. ${ }^{9}$

Pada tahun 2001 Direktorat Jenderal Binapenta dibubarkan dan diganti Direktorat Jenderal Penempatan dan Perlindungan Tenaga Kerja Luar Negeri yang selanjutnya disingkat PPTKLN sekaligus membubarkan Direktorat PTKLN.Direktorat Jenderal PPTKLN pun membentuk struktur Direktorat Sosialisasi dan Penempatan untuk pelayanan penempatan TKI ke luar negeri.Sejak kehadiran Direktorat Jenderal PPTKLN, pelayanan penempatan TKI di tingkat provinsi/kanwil dijalankan oleh BP2TKI.

Pada 2004 lahir Undang-Undang Nomor 39 Tahun 2004 Tentang Penempatan dan Perlindungan Tenaga Kerja Indonesia di Luar Negeri, yang pada pasal 94 ayat (1) dan (2) mengamanatkan pembentukan BNP2TKI). Kemudian disusul dengan lahirnya Peraturan Presiden Nomor 81 Tahun 2006 Tentang Pembentukan BNP2TKI yang struktur operasional kerjanya melibatkan unsurunsur instansi pemerintah pusat terkait pelayanan TKI, antara lain Kementerian Luar Negeri, Kementerian Perhubungan, Kementerian Tenaga Kerja dan Trasmigrasi, Kepolisian, Kementerian Sosial, Kementerian Pendidikan Nasional, Kementerian Kesehatan , Imigrasi (Kementerian Hukum dan Hak Asasi Manusia), Sekretariat Negara, dan lain-lain. ${ }^{10}$

Pada 2006 pemerintah mulai melaksanakan penempatan TKI program Government to Government ( $\mathrm{G}$ to $\mathrm{G}$ ) atau antarpemerintah ke Korea Selatan melalui Direktorat Penempatan dan Perlindungan Tenaga Kerja Luar Negeri (PPTKLN) di bawah Direktorat Jenderal PPTKLN Depnakertrans.

Pada 2007 awal ditunjuk Moh Jumhur Hidayat sebagai Kepala BNP2TKI melalui Keputusan Presiden Nomor 02 Tahun 2007 Tentang Pengesahan ASEAN Tourism Agreement (Persetujuan Pariwisata ASEAN), yang kewenangannya berada di bawah dan bertanggung jawab kepada presiden.

Tidak lama setelah Keppres pengangkatan itu yang disusul pelantikan Moh Jumhur Hidayat selaku Kepala BNP2TKI, dikeluarkan Peraturan Kepala BNP2TKI No 01/2007 tentang Struktur Organisasi BNP2TKI yang meliputi 
unsur-unsur intansi pemerintah tingkat pusat terkait pelayanan TKI. Dasar peraturan ini adalah Instruksi Presiden (Inpres) Nomor 6Tahun 2006 Tentang Kebijakan Reformasi Sistem Penempatan dan Perlindungan Tenaga Kerja Indonesia.

Dengan kehadiran BNP2TKI ini maka segala urusan kegiatan penempatan dan perlindungan TKI berada dalam otoritas BNP2TKI, yang dikoordinasi Menteri Tenaga Kerja dan Transmigrasi namun tanggung jawab tugasnya kepada presiden.Akibat kehadiran BNP2TKI pula, keberadaan Direktorat Jenderal PPTKLN otomatis bubar berikut Direktorat PPTKLN karena fungsinya telah beralih ke BNP2TKI.

Program penempatan TKI Government to Government ( $G$ to $G$ ) ke Korea pun dilanjutkan oleh BNP2TKI, bahkan program tersebut diperluas BNP2TKI bekerjasama pemerintah Jepang untuk penempatan G to G TKI perawat pada tahun 2008, baik untuk perawat rumahsakit maupun perawat lanjut usia.

Dasar hukum BNP2TKI yang melakukan pelayanan penempatan dan perlindungan TKI diluar penempatan pemerintah yang berbunyi di Pasal 95 ayat (1) dan ayat (2) Undang-Undang Nomor 39 Tahun 2004 tentang Penempatan dan Perlindungan Tenaga Kerja mengingat pasar kerja dalam negeri pemerintah dapat mengatur permintaan dan penawaran secara bersama-sama, sedangkan pasar kerja luar negeri masing-masing pemerintah Negara hanya dapat mengendalikan dari satu sisi saja itu yaitu pemerintahan Negara pengirim seperti Indonesia hanya dapat mengendalikan dari segi permintaan, sedangkan pemerintahan Negara menerima mengendalikan dari segi permintaan.

Menurut Pasal 1 Undang-Undang Nomor 13 Tahun 2003 Tentang Ketenagakerjaan, yang dimaksud dengan tenaga kerja adalah: "setiap orang yang mampu melakukan perkerjaan dan penghasilan yang layak bagi kemanusiaan.”

Terbatasnya lapangan pekerjaan di Indonesia, sementara kebutuhan Negara lain terhadap Tenaga Kerja Inonesia, maka dimanfaatkan oleh sebagian pekerja Indonesia mengisi posisi sebagai pekerja di Negara lain yang disebut juga dengan pekerja migrant.

Dimaksud dengan pekerja migran adalah orang yang bermigrasi dari wilayah kelahirannya ketempat lain dan kemudian bekerja ditempat yang bari 
tersebut dalam jangka waktu relatif menetap. Pada dasarnya ada dua pengelompokan faktor-faktor yang menyebabkan seseorang melakukan migrasi, yaitu faktor pendorong (push factor) dan faktor penarik (pull factor).

a. Faktor-faktor pendorong (push factor) antara lain adalah:

1. Makin berkurangnya sumber-sumber kehidupan seperti menurunnya daya dukung lingkungan, menurunnya permintaan atas barang-barang tertentu yang bahan bakunya makin susah diperoleh seperti hasil tambang, kayu atau bahan dari pertanian;

2. Menyempitnya lapangan pekerjaan ditempat asal (misalnya tanah untuk pertanian di wilayah pedesaan yang makin menyempit);

3. Adanya tekanan-tekanan seperti politik, agama, dan suku sehingga menganggu hak asasi penduduk di daerah asal.

4. Alasan pendidikan, pekerjaan dan perkawinan.

5. Bencana alam seperti banjir, kebakaran, gempa bumi, tsunami, musim kemarau panjang atau adanya wabah penyakit.

b. Faktor-faktor penarik ( pull factor ) antara lain adalah :

1. Adanya harapan akan memperoleh kesempatan untuk memperbaiki taraf hidup

2. Adanya kesempatan untuk memperoleh pendidikan yang lebih baik.

3. Keadaan lingkungan dan keadaan hidup yang menyenangkan, misalnya iklim, perumahan, sekolah dan fasilitas-fasilitas publik lainnya.

\section{Peran dan Tanggung Jawab Kementerian Luar Negeri Terhadap WNI dan TKI di Luar Negeri}

WNI dan TKI baik yang legal maupun illegal maka dalam hal perlindunganya menjadi tanggung jawab pemerintahsesuai amanat Undangundang Nomor 21 Tahun 2007 Tentang Pemberantasan Tindak Pidana Perdagangan Orang (TPPO). Pasal 1dalam Undang-Undang ini yang dimaksud dengan Perdagangan Orang adalah tindakan perekrutan,pengangkutan, penampungan,pengiriman, pemindahan, ataupenerimaan seseorang dengan ancaman kekerasan,penggunaan kekerasan, penculikan,penyekapan, pemalsuan,penipuan, penyalahgunaan kekuasaan atau posisi rentan,penjeratan 
utang atau memberi bayaran atau manfaat,sehingga memperoleh persetujuan dari orang yang memegang kendali atas orang lain tersebut, baik yang dilakukan di dalam negara maupun antar negara, untuk tujuan eksploitasi atau mengakibatkan orang tereksploitasi. ${ }^{11}$

Dilihat dari konseptual diatas, makaperlindungan WNI dan TKI di luar negeri dikaitkan dengan peraturan perundang-undangan yang berlaku di Indonesia yaitu:

1. Undang-Undang Republik Indonesia Nomor 21 Tahun 2007 Tentang Pemberantasn Tindak Pidana Perdagangan Orang (TPPO);

2. Badan Nasional Penempatan dan Perlindungan selanjutnya disingkat BNP2TKI di Luar Neneri;

3. Peraturan Menteri Luar Negeri Nomor 4 Tahun 2008 tentang Pelayanan Warga;

4. Keputusan Menteri Tenaga Kerja Nomor 260 Tahun 2015 Tentang Penghentian dan Pelarangan Penempatan TKI Pada Pengguna Perseorangan di Negara-Negara Kawasan Timur Tengah.

Perlindungan ini terkaitan dengan penipuan terhadap calon TKI terutama tenaga kerja wanita yang bekerja tidak sesuai yang diperjanjikan seperti menjadi eksploitasi prostitusi, dan/atau beban pekerjaan yang terlalu berat tidak sesuai dengan kemampuan TKI.Eksploitasi meliputi, setidaknya, eksploitasi prostitusi terhadap orang lain atau bentuk lain eksploitasi seksual lainnya, kerja atau layanan paksa, perbudakan atau praktek yang serupa dengan perbudakan, penghambaan atau pengambilan organ tubuh. ${ }^{12}$

Berdasarkan Pasal 1 (2)menyebutkan: "Tindakan Pidana Perdagangan Orang adalah setiap tindakan atau serangkaian tindakan yang memenuhi unsurunsur tindak pidana yang ditentukan dalam undang-undang ini”.

\footnotetext{
${ }^{11}$ Diambil pada 05 Mei 2016 dari http://www.dpr.go.id/dokjdih/document/uu/UU_2007_21.pdf

${ }^{12}$ International Organization for Migration (IOM), Rapat Koordinasi Kementerian Luar Negeri \& Pemerintah Daerah 'WNI Korban TPPO dari Luar Negeri dan di Daerah Perbatasan, Batam, 12 Desember 2013
} 
Oleh sebab itu, perlu langkah strategis pemberantasan TPPO di luar negeri dengan mengacu pada apa yang telah menjadi kesepakatan antara lain: ${ }^{13}$

1. Ratifikasi Konvensi PBB Menentang Tindak Pidana Lintas Negara Terorganisir (UNTOC) melalui UU No. 5 Tahun 2009.

2. Ratifikasi Protokol untuk Mencegah, Minindak dan Menghukum Perdagangan Orang, terutama Perempuan dan Anak-Anak melalui UU No. 14 Tahun 2009.

3. Bali Process on People Smuggling, Trafficking in Persons, and Related Transnational Crime.

4. Forum-Forum Regional ASEAN

WNI korban TPPO di luar negeri bisa dilihat pada table dibawah ini yang Negara paling banyak melakukan TPPO adalah Malaysia, sebuah Negara yang paling banyak menyerap TKI . Tahun 2012 sebanyak 199 orang WNI korban TPPO, dan menurun di tahun 2013 sebanyak 142 orang WNI, kemudian Persatuan Emirat Arab sebanyak 19 orang WNI korban TPPO, yang turun menjadi 3 orang WNI pada tahun 2013.

WNI KORBAN TINDAK PIDANA PERDAGANGAN ORANG (TPPO) TAHUN $2012-2013$ (s.d. 10 Desember 2013) ${ }^{14}$

\begin{tabular}{|c|l|c|c|}
\hline \multirow{2}{*}{ NO } & \multirow{2}{*}{ NEGARA } & \multicolumn{2}{c|}{ WNI KORBAN TPPO } \\
\cline { 3 - 4 } & & $\mathbf{2 0 1 2}$ & $\mathbf{2 0 1 3}(\mathbf{1 0}$ DESEMBER) \\
\hline 1 & AMERIKA SERIKAT & 1 & 0 \\
\hline 2 & AUSTRALIA & 0 & 1 \\
\hline 3 & BRUNEI DARUSSALAM & 1 & 0 \\
\hline 4 & CINA & 1 & 1 \\
\hline 5 & KOREA SELATAN & 1 & 0 \\
\hline 6 & KUWAIT & 1 & 0 \\
\hline
\end{tabular}

\footnotetext{
${ }^{13}$ Tatang Budie Utama Razak, Direktur Perlindungan WNI dan BHI Direktorat Jenderal Protokal dan Konsuler Kementerian Luar Negeri RI, Disampaikan pada:Rapat Koordinasi Kementerian Luar Negeri RI dengan Pemerintah Daerah "Penanganan WNI/TKI Korban TPPO di Luar Negeri dan di Daerah Perbatasan"Batam, 11-13 Desember 2013

${ }^{14}$ ibid
} 


\begin{tabular}{|c|l|c|c|}
\hline 7 & MALAYSIA & 199 & 125 \\
\hline 8 & MESIR & 17 & 6 \\
\hline 9 & PAPUA NEW GUINEA & 0 & 1 \\
\hline 10 & PERSATUAN EMIRAT ARAB & 19 & 3 \\
\hline 11 & SURIAH & 10 & 1 \\
\hline 12 & YORDANIA & 218 & 8 \\
\hline & JUMLAH & $\mathbf{4 6 8}$ & $\mathbf{1 4 6}$ \\
\hline & TOTAL & $\mathbf{6 1 4}$ \\
\hline
\end{tabular}

Warga Negara Indonesia di Luar Negeri sebanyak 4.227.383 jiwa, yang TKI berdasarkan wilayah sebagai berikut: ${ }^{15}$

Wilayah Asia $\quad$ : 2.654.796 jiwa

Timur Tengah $\quad: 1.205 .652$ jiwa

Amerika $\quad: 185.159$ jiwa

Pasific $\quad: \quad 90.455$ jiwa

Eropa $\quad: 85.393$ jiwa

Afrika $\quad: 5.918$ jiwa

Sedangkan berdasarkan status sebagai brikut:

Tenaga Kerja Indonesia (TKI ) : 2.536 .429 orang (60\%)

Pelajar $\quad$ : 845.476 orang (20\%)

Profesional $\quad: 338.190$ orang $(8 \%)$

Anak Buah Kapal (ABK) : : $253.642(6 \%)$

Lainnya : $253.646(6 \%)$

Pengertian Perdagangan Orang adalah Tindakan perekrutan, pengangkutan, penampungan, pengiriman, pemindahan, atau penerimaan seseorang dengan ancaman kekerasan, penggunaan kekerasan, penculikan, penyekapan, pemalsuan, penipuan, dan penyalahgunaan kekuasaan atau posisi

\footnotetext{
${ }^{15}$ Wagiran, Kemenko Kesra, PENANGANAN WNI KORBAN TPPO DARI LUAR NEGERI DAN DAERAH PERBATASAN: Dinamika Koordinasi dan Hambatan di Lapangan Batam, 12 Desember 2013
} 
rentan, penjeratan utang, atau memberikan bayaran atau manfaat, sehingga memperoleh persetujuan dari orang yang memegang kendali atas orang lain tersebut, baik yang dilakukan di dalam negara maupun antar negara, untuk tujuan eksploitasi atau mengakibatkan orang tereksploitasi. ${ }^{16}$

Realita migrasi TKI adalah pelanggaran hak-hak perburuhan dan kontrak yang sering terjadi adalah sebagai berikut:

1. Perekrutan Ilegal

2. Kekerasan Seksual

3. Situasi kerja yang berbahaya

4. Kekerasan fisik dan physikologis

5. Kecelakaan Kerja dan Kematian

6. Diskriminasi

7. Marginalisasi

8. Kesepian \& kehancuran keluarga

Berdasarkan data kementerian Luar Negeri, maka konsentrasi WNI di Luar Negeri adalah di wilayah Asia sebanyak 3.363.220 jiwa (62.80 \%), Timur Tengah sebanyak 976.916 jiwa (28.52 \%) , Amerika sebanyak 130.908 jiwa, Pasifik sebanyak 72.160 jiwa( $2.14 \%$ ), Eropa sebanyak 64.203 jiwa (2.02 \%), Afrika sebanyak 4.939 jiwa $(0.14 \%){ }^{17}$

Sedangkan jumlah TKI di luar negeri tahun 2012 sebanyak 2.536.429 jiwa, dan dari jumlah itu TKI formal sebanyak 920.621 orang (36.3\%), dan TKI informal sebanyak 1.615.808 orang (63.7\%). Tapi pihak Kementerian Luar Negeri memberikan catatan bahwa jumlah TKI di luar negeri kemungkinan besar 2 atau 3 kali lipat.Kemlu mendapatkan data dari Perwakilan RI berdasarkan lapor diri dan pembuatan dokumen perjalanan.Sesuai ketentuan seharusnya PPTKIS melaporkan data TKI yang dikirim ke luar negeri ke Perwakilan RI, namun tidak dilakukan sebesar $+84 \%$ dari jumlah TKI informal tersebut adalah Penata Laksana Rumah Tangga (PLRT).

Ada beberapa faktor akar masalah Negara tujuan para TKI, yakni beberapa diantara penempatam atau tujuan, tidak memiliki undang-undang atau hukum

\footnotetext{
${ }^{16}$ Wagiran-ibid

17 Tatang Budie Utama Razak, Loc.it
} 
mengenai ketenagakerjaan yang memadai.Jika muncul masalah antara user dengan pekerja, seringkali merugikan pekerja karena pendekatan yang digunakan oleh negara penempatan berbeda dan kecenderungan di tiap negara adalah bahwa sistem pengadilan dan penegakan hukum di negara tersebut akan melindungi warga negara tersebut dan mengalahkan warga negara asing

Cara pandang masyarakat setempat di beberapa negara penempatan yang melihat bahwa pekerja asing yang bekerja di bidang konstruksi, perkebunan, dan PLRT dianggap pekerjaan yang rendah (difficult, dangerous, and dirty) sehingga kurang dihargai.

Pada beberapa negara, permasalahan domestik workers dianggap sebagai bagian dari permasalahan keluarga atau dianggap masalah individu dan bukan pemerintah/negara.

\section{Peran Direktorat Perlindungan WNI dan Bantuan Hukum ( BHI)}

Berdasarkan Peraturan Menteri Luar Negeri RI Nomor 01/A/ OT/I/2006/01 Tahun 2006, Direktorat Perlindungan Warga Negara Indonesia dan Badan Hukum Indonesia (PWNI dan BHI) bertugas memberikan perlindungan WNI di dalam dan luar negeri, badan hukum Indonesia di luar negeri, pengawasan kekonsuleran, serta bantuan sosial dan repatriasi WNI.Direktorat PWNI dan BHI terdiri dari $:^{18}$

a) Subdirektorat PWNI dan BHI di luar negeri (Subdit I),

b) Subdirektorat PWNI di Indonesia (Subdit II), Subdirektorat Pengawasan Kekonsuleran (Subdit III),

c) Subdirektorat Bantuan Sosial dan Repatriasi WNI (Subdit IV), dan Subbagian Tata Usaha.

Sub Direktorat ini kemudian dibagi pula tugas, tanggungjawabnya yaitu:

1) Subdit I meliputi Negara Malaysia, Suria, Jordan, Amerika, Yaman, Lebanon, dan Irak;

2) Subdit II meliputi Negara Arab Saudi, Oman, Korea, dan Kawasan Eropa;

3) Subdit III meliputi Negara ASEAN selain Malaysia, Australia, Asia Selatan dan Tengah, Kawasan Afrika, Persatuan Emirat Arab;

\footnotetext{
${ }^{18}$ Direktorat Perlindungan Warga Negara Indonesia (WNI ) dan Bantuan Hukum Indonesia (BHI), Kemlu RI
} 
4) Subdit IV meliputi Kuwait, Qatar, Bahrain, Jepang, China, Hongkong, Taiwan, Negara-negara di Pasifik selain Australia

Subdirektorat Pengawasan Kekonsuleran antara lain bertugas menangani pelayanan publik dan akses konsuler terkait dengan data dan penyampaian informasi, serta pelayanan dan perlindungan hak-hak WNI terkait masalah keimigrasian, kewarganegaraan, dan kependudukan. Hak-hak WNI yang bermasalah atau terlantar, perlindungan hak-hak pelaut Indonesia yang menghadapi masalah di kapal angkut asing dan atau di luar negeri, hak-hak pelaut dan nelayan Indonesia yang menghadapi masalah di kapal penangkap ikan asing dan atau di luar negeri, penyelesaian permasalahan WNI dan BHI di luar negeri.

Selain itu ada Subdirektorat Bantuan Sosial dan Repatriasi WNI bertugas menangani pelayanan di bidang bantuan kemanusiaan, pemulangan WNI bermasalah dan atau terlantar di luar negeri, antara lain mengenai pemberian uang santunan, kompensasi, asuransi dan proses pemulangan ke daerah asal, pemberian fasilitas kesehatan, penyediaan informasi umum dan dokumen, penjemputan, melakukan monitoring terhadap WNI/TKI korban human trafficking dan transnasional crimes lainnya. Subbagian Tata Usaha adalah sebagai unsur pendukung yang bertugas melaksanakan ketatausahaan dan kerumahtanggaan, seperti perencanaan dan pelaporan kinerja, administrasi keuangan, administrasi kepegawaian, dan administrasi perlengkapan. ${ }^{19}$

\section{Kasus-kasus TKI di Malaysia Ditangani Kementerial Luar Negeri Indonesia di Malaysia}

TKI yang paling banyak berada di Malaysia sebanyak lebih dari 60 persen, akibatnya kasus-kasus pun sering muncul dan menjadi perhatian Pemerintah Indonesia. Jumlah WNI PATI (pendatang asing tanpa izin) di Malaysia (berdasarkan data Kementerian Dalam Negeri Malaysia sebanyak 640.609 orang

Jumlah WNI PATI yang telah didokumentasikan untuk dipulangkan hingga September 2012 sebnyak 379.310 orang. Jumlah Paspor dan Surat Perjalanan Laksana Paspor (SPLP) yang telah dikeluarkan oleh Perwakilan RI di Malaysia hingga September 2012 342.943 Paspor dan 36.367 SPLP.Pada tanggal

\footnotetext{
${ }^{19}$ Diambil pada 06 Mei 2016 dari:http://www.tabloiddiplomasi.org/previous-isuue/37-juni-2009edisi-pelayanan-publik/558-tugas-dan-fungsi-direktorat-pwni-dan-bhi.html
} 
22 Juli 2013, Menteri Dalam Negeri Malaysia menyampaikan bahwa Pemerintahnya akan melaksanakan tahap ke-5 dari program 6P yaitu operasi Penguatkuasaan (Penegakan Hukum) terhadap PATI. Terdapat kemungkinan sekitar 200.000 orang WNI yang akan terkena operasi tersebut. ${ }^{20}$

Kasus-kasus Penembakan WNI oleh Polisi Diraja Malaysia yang tercata dalam media vivanews, 13 November 2012 dimuat bahwa Hishammuddin Hussein, Mendagri Malaysia dalam pernyataan tertulis menyampaikan sejak 2007 hingga Agustus 2012 terdapat 151 WNI yang ditembak mati di Malaysia yang terlibat dalam berbagai kasus criminal. ${ }^{21}$

Akar permasalahan WNI di luar negeri ada beberapa factor yakni:

\section{Faktor Individu}

1.1. Latar belakang sosial ekonomi, kemiskinan, dan pengangguran menjadi faktor pendorong orang menerima tawaran dengan mudah, tanpa mempertimbangkan resiko yang akan dipikul

1.2. Menonjolnya kepentingan untuk meraih keuntungan ekonomis dari individu atau kelompok tertentu dengan mengabaikan akibat yang timbul dari penempatan tersebut khususnya yang tidak sesuai prosedur dan ketentuan;

1.3. Rendahnya tingkat pendidikan dan skill, membuat TKI pada umumnya hanya dapat mengisi sektor-sektor domestik (buruh bangunan, buruh perkebunan dan PLRT);

1.4. Kurangnya kesadaran masyarakat untuk mengikuti prosedur serta kemampuan adaptasi membuat TKI seringkali mengalami culture shock di negara tujuan penempatan;

\section{Faktor Pemerintah}

2.1. Belum optimalnya koordinasi antar instansi terkait, sehingga kurang terjadi sinergi dalam pelaksanaan tupoksi, program kerja maupun alokasi anggaran antar Kementerian/Lembaga maupun stakeholder terkait;

2.2. Belum optimalnya law enforcement di dalam negeri sehingga tidak menimbulkan efek jera kepada oknum-oknum yang melakukan

\footnotetext{
${ }^{20}$ Tatang Budie Utama Razak, Loc.it.

${ }^{21}$ ibid
} 
penyimpangan dalam proses perekrutan, pelatihan dan penempatan TKI ke luar negeri;

2.3. Lemahnya kontrol di titik-titik perbatasan baik darat, laut, maupun udara;

Perbedaan persepsi dan pendekatan dalam mengimplementasikan pelaksanaan peraturan penempatan dan perlindungan TKI;

2.4. Tidak dilaksanakannya UU No. 39 Tahun 2004 secara utuh yang berimplikasi pada lemahnya posisi tawar (bargaining position) Indonesia dengan negara penempatan.

2.5. Masih belum sempurnanya substansi dan implementasi dari UU Nomor 39 Tahun 2004 yaitu antara lain:

2.5.1. Substansi yang lebih banyak mengatur mengenai aspek bisnis penempatan TKI ke luar negeri dibandingkan aspek perlindungan.

2.5.2. Pendekatan yang digunakan dalam prosedur penempatan TKI hanya untuk TKI sector PLRT dan belum menyentuh aspek TKI Formal atau sektor lainnya seperti permasalahan ABK.

3. Faktor Negara Tujuan

3.1. Beberapa diantara negara penempatan/tujuan, tidak memiliki undangundang/hukum mengenai ketenagakerjaan yang memadai;

3.2. Jika muncul masalah antara user dengan pekerja, seringkali merugikan pekerja karena pendekatan yang digunakan oleh negara penempatan berbeda dan kecenderungan di tiap negara adalah bahwa sistem pengadilan dan penegakan hukum di negara tersebut akan melindungi warga negara tersebut dan mengalahkan warga negara asing;

3.3. Cara pandang masyarakat setempat di beberapa negara penempatan yang melihat bahwa pekerja asing yang bekerja di bidang konstruksi, perkebunan, dan PLRT dianggap pekerjaan yang rendah (difficult, dangerous, and dirty) sehingga kurang dihargai;

3.4. Pada beberapa negara, permasalahan domestic workers dianggap sebagai bagian dari permasalahan keluarga atau dianggap masalah individu dan bukan masalah pemerintah/negara. 
4. Faktor Perusahaan Pengerah Penempatan

4.1. Banyaknya PPTKIS yang hanya mengutamakan kepentingan bisnis dengan pengiriman TKI sebanyak-banyaknya ke luar negeri tanpa memperhatikan sistem perekrutan yang baik, sistem pelatihan yang benar, sistem pemeriksaan kesehatan, sistem administrasi yang baik yang sesuai dengan prosedur dan peraturan yang ada;

4.2. Proses pelatihan dan pembekalan keterampilan Calon TKI yang belum optimal;

4.3. Tidak dilaksanakannya kewajiban-kewajiban Perusahaan Pengarah Tenaga Kerja Indonesia Swasta (PPTKIS) sebagaimana diamanatkan dalam Undang-Undang Nomor 39 Tahun 2004 Tentang Penempatan dan Perlindungan Tenaga Kerja Indonesia di Luar Negeri.

Yang menjadi akar permasalahan soal TPPO adalah sebagai berikut:

1. Banyaknya penduduk yang hidup di bawah garis kemiskinan;

2. Lapangan pekerjaan yang tidak mencukupi;

3. Rendahnya tingkat pendidikan, khususnya di daerah-daerah pelosok.

4. Khusus untuk TKI, proses rekrutmen dan pemberangkatan TKI yang tidak mengikuti sistem yang sudah ditetapkan oleh Pemerintah dan Undang Undang (pemalsuan dokumen identitas dan perjalanan, rekrutmen langsung oleh sponsor, kompetensi TKI yang tidak memadai untuk bekerja di luar negeri).

Modus operandi TPPO dengan cara dalah pengiriman tenaga kerja, Duta Seni Budaya, Perkawinan Pesanan, Pengangkatan Anak,Pemalsuan Dokumen, Penyalahgunaan Visa, Pemindahan Tenaga Kerja Prosedural yang Dipindahkan Secara Ilegal, Penjeratan Hutang, Kerja Paksa.

Langkah strategis pemberantasan TPPO di dalam negeri yakni pemberlakuan Undang-undang Nomoro 21 Tahun 2007 Tentang Pemberantasan Tindak Pidana Perdagangan Orang. Pasal 1 ayat (1) menyebutkan:

'Perdagangan Orang adalah tindakan perekrutan, pengangkutan, penampungan, pengiriman, pemindahan, atau penerimaan seseorang dengan ancaman kekerasan, penggunaan kekerasan, penculikan, penyekapan, pemalsuan, penipuan, penyalahgunaan kekuasaan atau posisi rentan, penjeratan utang atau memberi bayaran atau manfaat, 
sehingga memperoleh persetujuan dari orang yang memegang kendali atas orang lain tersebut, baik yang dilakukan di dalam negara maupun antar negara, untuk tujuan eksploitasi atau mengakibatkan Pasal 58 orang tereksploitasi”.

ayat (1) berbunyi:

"Untuk melaksanakan pemberantasan tindak pidana perdagangan orang, Pemerintah dan Pemerintah Daerah wajib mengambil langkah-langkah untuk pencegahan dan penanganan tindak pidana perdagangan orang.

ayat(2)berbunyi:

"Untuk mengefektifkan dan menjamin pelaksanaan langkah- langkah sebagaimana dimaksud pada ayat (1) Pemerintah membentuk gugus tugas yang beranggotakan wakil-wakil dari pemerintah, penegak hukum, organisasi masyarakat, lembaga swadaya masyarakat, organisasi profesi, dan peneliti/ akademisi.

Selain itu pembentukan Gugus Tugas Pencegahan dan Penanganan Tindak

Pidana Perdagangan Orang melalui Peraturan Presiden No. 69 tahun 2008.

\section{E. KESIMPULAN DAN SARAN}

\section{KESIMPULAN}

Timbulnya kasus yang umumnya menimpa TKI bukan semata-mata faktor individu yang belum tergolong dewasa dan/atau pendidikan rendah, tapi peran BNP2TKI yang merupakan filter atau penyaring TKI ke luar negerisesuai wewenangnya belum maksimal, sehingga masih banyak yang lolos bekerja di luar negeri tanpa dokumen sesuai peraturan perundangundang Negara tujuan. Lolosnya Welfrida yang usianya masih 13 tahun, ini membuktikan terjadi penjualan orang (trafficking).Kementerian Luar Negeri dapat mengemplementasikan peran, fungsi dan tanggungjawabnya terhadap WNI dan TKI di luar negeri karena memiliki kompetensi dan jaringan diplomatik, apalagi bila dikaitkan dengan WNI/TKI terpaksa pulang dari Negara tempatnya bekerja atau sekolah, dan/atau pebisnis akibat terjadi bencana alam, perang saudara, atau komflik politik, dan/atau TKI yang dianiaya majikan dan lain-lain. Peran ini tidak bisa diambil pihak lain, apalagi oleh sebuah lembaga non-pemerintah, karena bisa timbul konflik-interest, yang berbeda dengan Kementerian Luar Negeri yang didalamnya mengemban tugas Negara. 


\section{SARAN}

Untuk lebih meningkatkan efektifitas pencegahan dan perlindungan WNI/TKI di luar negeri, maka peran BNP2TKI perlu dibenahi dan harus diisi personil yang tidak memikirkan kepentingan kelompok dan/atau komunitas tertentu, tanpa memikirkan akibat yang bakal menimpa TKI/WNI di luar negeri. Pelabuhan laut illegal yang banyak terdapat di daerah perbatasan seperti Batam, Tanjung Pinang dan Bintan harus ditertibkan, dan ditempat petugas BNP2TKI yang dependable, bertanggungjawab, serta memiliki misi menyelamatkan warga Negara Indonesia, bukan mencari keuntungan pribadi.

\section{DAFTAR PUSTAKA}

\section{A. Buku}

Achmad Ali, dan .Wiwie Heryanil, Menjelajahi Kajian Empiris terhadap Hukum, Jakarta: Kencana Prenada Media Group, 2012.

Ahmadi Miru dan Sakka Pati, Hukum Perikatan Penjelasan Makna Pasal 1233 sampai 1456 BW, Jakarta: Rajagrafindo Persada.

\section{B. Peraturan Perundang-Undangan}

1. Undang-Undang Republik Indonesia Nomor 21 Tahun 2007 Tentang Pemberantasn Tindak Pidana Perdagangan Orang (TPPO);

2. Badan Nasional Penempatan dan Perlindungan selanjutnya disingkat BNP2TKI di Luar Neneri;

3. Peraturan Menteri Luar Negeri Nomor 4 Tahun 2008 tentang Pelayanan Warga;

4. Keputusan Menteri Tenaga Kerja Nomor 260 Tahun 2015 Tentang Penghentian dan Pelarangan Penempatan TKI Pada Pengguna Perseorangan di Negara-Negara Kawasan Timur Tengah.

\section{Workshop/Seminar/Lokakarya}

Direktorat Perlindungan Warga Negara Indonesia (WNI ) dan Bantuan Hukum Indonesia (BHI), Kemlu RI 
Wagiran, Kemenko Kesra, PENANGANAN WNI KORBAN TPPO DARI LUAR NEGERI DAN DAERAH PERBATASAN: Dinamika Koordinasi dan Hambatan di Lapangan,Batam, 12 Desember 2013

International Organization for Migration (IOM), Rapat Koordinasi Kementerian Luar Negeri \& Pemerintah Daerah 'WNI Korban TPPO dari Luar Negeri dan di Daerah Perbatasan, Batam, 12 Desember 2013

Tatang Budie Utama Razak, Direktur Perlindungan WNI dan BHI Direktorat Jenderal Protokal dan Konsuler Kementerian Luar Negeri RI, Disampaikan pada:Rapat Koordinasi Kementerian Luar Negeri RI dengan Pemerintah Daerah "Penanganan WNI/TKI Korban TPPO di Luar Negeri dan di Daerah Perbatasan"Batam, 11-13 Desember 2013

\section{Internet}

Diambil pada 06 Mei 2016 dari: http://www.tabloiddiplomasi.org/previousisuue/37-juni-2009- edisi-pelayanan-publik/558-tugas-dan-fungsi-direktoratpwni-dan-bhi.html

Diambil pada $05 \quad$ Mei 2016 dari http://www.dpr.go.id/dokjdih/document/uu/UU_2007_21.pdf

Diambil pada 06 Mei 2016 dari- http://www.bnp2tki.go.id/frame/9003/SejarahPenempatan-TKI- Hingga-BNP2TKI

Diambil pada $06 \quad$ Mei 2016 dari: http://www.tabloiddiplomasi.org/previous-isuue/37-juni-2009-edisipelayanan-publik/558-tugas-dan-fungsi-direktorat-pwni-dan-bhi.html

Diambil pada 05 Mei 2016 dari- http://www.imigrasi.go.id/index.php/berita/beritautama/280-imigrasi-batam-sosialisasi-patroli-pelabuhan-tikus-ke-warga-pesisir

Diambil pada Hari Selasa, tanggal 27 April 2016 dari www.hukumonline.com

Andrian Ramadhan, kategori-umur-menurut-depkes-ri-2009. Diambil pada 05 April 2016 dari http://arfkomunika.blogspot.co.id/2014/01/

DianaKusumasari,perbedaan-batasan-usia-cakap-hukum-dalamperaturan-perundang-undangan. Diambil pada 05 April 2016 dari http://www.hukumonline.com/klinik/detail/lt4eec5db1d36b7

Diambil pada $04 \quad$ April $2016 \quad$ dari http://m.tempo.co/read/news/2013/09/27/058517147/Yohanes Seo- OrangTua-Walfrida-Diberangkatkan-ke-Malaysia- 
DianaKusumasari,perbedaan-batasan-usia-cakap-hukum-dalam-peraturan perundang-undangan. Diambil pada 05 April 2016 dari http://www.hukumonline.com/klinik/detail/lt4eec5db1d36b7

Diambil pada tanggal $05 \quad$ Mei 2016 dari http://www.dpr.go.id/dokjdih/document/uu/UU_2007_21.pdf

Diambil pada $06 \quad$ Mei $2016 \quad$ darihttp://www.bnp2tki.go.id/frame/9003/Sejarah-Penempatan-TKI- HinggaBNP2TKI

Diambil pada $05 \quad$ Mei 2016dari

http://www.imigrasi.go.id/index.php/berita/berita-utama/280-imigrasi-batamsosialisasi-patroli-pelabuhan-tikus-ke-warga-pesisir

Diambil pada Hari Selasa, tanggal 27 April 2016 dari www.hukumonline.com

Andrian Ramadhan, kategori-umur-menurut-depkes-ri-2009. Diambil pada 05 April 2016 dari http://arfkomunika.blogspot.co.id/2014/01/

Yohanes Seo- Orang-Tua-Walfrida-Diberangkatkan-ke-Malaysia-Diambil pada 04 April 2016 dari http://m.tempo.co/read/news/2013/09/27/058517147/ 